\title{
Lærerens rolle og elevens medvirkning i den spesialpedagogiske tiltakskjede
}

Av Lise Øen Jones, førsteamanuensis ved Universitetet i Bergen og førsteamanuensis II ved NLA Høgskolen og Elisabeth Hesjedal, førsteamanuensis ved Universitetet i Bergen

\section{Sammendrag}

Artikkelen undersøker lærerens rolle i den spesialpedagogiske tiltakskjeden og videre hvordan elevens medvirkning kan inkluderes i denne prosessen. Tiltakskjeden består av seks faser hvor lærerens rolle er særlig viktig i første, femte og sjette fase. Med utgangspunkt i Lindensjö \& Lundgrens (2000) begreper formulering- og realiseringsarenaen, vil vi gjennom et litteratursøk undersøke hva sentrale dokumenter og forskning sier om lærerens rolle og ansvar i den spesialpedagogiske tiltakskjede. Formuleringsarenaen handler om intensjoner og føringer i eksempelvis offentlige styringsdokumenter, mens realiseringsarenaen viser til hvordan disse intensjonene blir iverksatt. I diskusjonsdelen brukes en modell inspirert av Lindensjö og Lundgren (2000) som en analytisk linse for å diskutere artikkelens problemstilling sammen med resultater fra litteratursøket. Våre funn viser at lærernes rolle og ansvar, og elevens medvirkning i liten grad er løftet frem i tiltakskjeden. Resultatet viser at fokus i utvalgte dokumenter og forskingslitteratur har vært/er mer rettet mot saksgang og prosedyrer enn mot lærers rolle, ansvar og barns medvirkning i denne prosessen.

Nøkkelord: spesialpedagogiske tiltakskjede, lærerrollen, elevmedvirkning 


\section{Abstract}

The present study examines the teacher's role in the chain of actions in special education, and furthermore how the pupil's participation can be included in this process. The chain of actions in special education consists of six phases, where the teacher plays a particularly important role in the first, fifth and sixth phase. Using the concepts from Lindensjö \& Lundgren (2000), the area of formulation and realization we will use a literature search to get an overview of central policy documents and research on how the teacher's role and responsibility in the chain of actions in special education is described. Whereas the area of formulation describes intentions and guidelines of e.g. policy documents, the area of realization describes how these intentions are implemented. In the discussion we use a model inspired by Lindensjö \& Lundgren (2000) as an analytical lens to discuss our research questions together with findings from our literature search. Our findings show that the teachers' role and responsibilities and the pupils' collaboration only to a small extent have been made evident in the chain of actions. In the documents that describe the teacher's role, we find that the focus is primarily on proceedings and procedures rather than on the teacher's responsibility and role in the chain of actions. Student's participation in this process is also given little attention.

Key words: special education, chain of actions, teacher's role, pupil's participation

\section{Introduksjon}

Gjennom våre utdanninger og erfaringer fra PP-tjenesten, skole og barnevern, tenker vi i tråd med Biesta (2013) at skole er mer enn bare fokus på prestasjoner med faglig kunnskap som mål. Skole dreier seg også om livet $\mathrm{i}$ og rundt den enkelte lærer og elev. For å følge opp sentrale retningslinjer i læreplanen og i Opplæringsloven (1998) må skolen og lærere ta hensyn til elevenes grunnleggende behov gjennom å gi en tilfredsstillende opplæring som sikrer trygghet og læring. For å imøtekomme dette, må læreren være 
bevisst sitt ansvar. Målet med artikkelen er å løfte frem lærerens rolle i grunnskolen og ansvaret en har for å identifisere og følge opp elever som har rett på spesialundervisning etter $\$ 5-1$ i Opplæringsloven (1998) i forbindelse med den spesialpedagogiske tiltakskjeden. Det overordnede forskningsspørsmålet for artikkelen er: Hva er larerens rolle og ansvar når det gjelder å folge opp elever som har rett på spesialundervisning? Vi har også inkludert elevens stemme og følger opp med forskningsspørsmålet: Hvordan kan elevens rett til medvirkning ivaretas $i$ denne prosessen? Ifølge Herlofsen (2014) eksisterer det svært lite forskning om læreren som aktør i tiltakskjeden og elevens rett til medvirkning i prosessen. Med utgangspunkt i Lindensjö \& Lundgrens (2000) begreper formulering- og realiseringsarenaen, vil vi gjennom et litteratursøk undersøke hva sentrale dokumenter og forskning sier om lærerens rolle og ansvar i den spesialpedagogiske tiltakskjede. Formuleringsarenaen handler om intensjoner og føringer i eksempelvis offentlige styringsdokumenter, mens realiseringsarenaen viser til hvordan disse intensjonene blir iverksatt. I diskusjonsdelen vil vi bruke en modell inspirert av Lindensjö og Lundgren (2000) som en analytisk linse for å diskutere artikkelens problemstilling sammen med resultater fra litteratursøket.

Alle elever i Norge har rett og plikt til 10-årig grunnskole (Opplæringsloven, 1998, \$ 2-1). Skolen har ansvar for å møte eleven der de er, både når det gjelder alder, variasjon i evner, behov og interesser. Derfor blir forholdet mellom inkludering, tilpasset opplæring og spesialundervisning kort forklart her. Befring (2018) beskriver inkludering som et «indrebegrep» da det er den enkeltes opplevelser og erfaringer som gjelder. Å være inkludert i skolen betyr dermed å få oppleve at en hører til, og er verdsatt som en aktiv deltager i skolefellesskapet (Befring 2018). Tilpasset opplæring er nedfelt i Opplæringsloven $(1998, \S 1-3)$ og blir ofte brukt som et tiltak i å realisere kravet skolen har for å imøtekomme alle elevene. Ifølge Haug (2013) handler det om å utvikle skolen på alle nivåer slik at den rommer alle og tar hensyn til den enkelte elev. Selv om prinsippet også ligger til grunn for Læreplanverket for Kunnskapsløftet (Kunnskapsdepartementet, 2006, LK 06), er det ikke en metode. Tilpasset opplæring er et generelt prinsipp, en retningslinje og rettsregel som på ulike vis blir utslagsgivende for hvordan opplæringen forstås og gjennomføres i praksis (Haug, 2013; Welstad, 2016). I motsetning til tilpasset opplæring, som beskrives som en kollektiv rettighet, er retten til spe- 
sialundervisning, gjennom sakkyndig vurdering og enkeltvedtak, en individuell juridisk rett hjemlet i opplæringsloven $(1998, \$ 5-1)$. Selv om eleven har rett til spesialundervisning, er det opp til eleven og/eller foreldrene å velge om eleven faktisk skal ha spesialundervisning. Eleven har ingen plikt til å motta spesialundervisning (Utdanningsdirektoratet, 2019). Ifølge Svele et al. (2018) er retten til spesialundervisning den mest sentrale rettighetsbestemmelsen i Opplæringsloven (1998), og et sikkerhetsnett for de elevene som ikke får et tilstrekkelig utbytte av den ordinære opplæringen. En vanlig tilnærmingsmåte til spesialundervisningen er å forstå denne innenfor en vid og en smal forståelse. En smal forståelse setter søkelys på konkrete vansker og funksjonsnedsettelser i eleven samt egnede undervisningsformer for denne type funksjonsnedsettelse. En vid forståelse av spesialpedagogikk setter søkelys på generelle prinsipper i undervisningen. Her tolker man spesialundervisningen som del av tilretteleggingen innenfor den ordinære, tilpassede opplæringen (Hausstätter, 2012).

\section{Tiltakskjeden}

For å iverksette lovens bestemmelser om spesialundervisning følges en saksgang som involverer flere aktører; rektor, kontaktlærer og Pedagogisk-psykologisk tjeneste, (PPT). De ulike fasene i saksgangen kalles for spesialundervisningens tiltakskjede (Utdanningsdirektoratet, 2019). Denne består av seks faser hvor det er naturlig at også foreldrene og eleven involverer seg (Utdanningsdirektoratet, 2019). Lærerens rolle i den spesialpedagogiske tiltakskjeden er spesielt viktig da læreren er en sentral aktør i første, femte og sjette fase.

I fase 1, før-tilmeldingsfasen/bekymringsfasen, er det pedagogiske personalet og kontaktlærer bekymret for en elevs faglige og/eller sosiale utvikling. Når læreren mener at eleven, til tross for tilpasningene i den ordinære opplæringen, ikke vil kunne få et tilfredsstillende utbytte, er det lærerens plikt å melde fra til rektor om dette (Utdanningsdirektoratet, 2019). Denne plikten er lovhjemlet i Opplæringslovens $(1998, \$ 5-4)$. Behovet for å vurdere spesialundervisning kan også komme fra foresatte og eleven selv (Opplæringsloven, 1998, $\$ 5-4)$. Første fase avsluttes med at rektor avgjør om eleven skal henvises til PPT eller ikke; om det konkluderes med å sende saken (bekymringsmelding) til PPT for å vurdere elevens behov for spesialunder- 
visning (sakkyndig vurdering), bør det legges ved en beskrivelse der skolens vurdering kommer frem. Rektor har ansvaret for å motta og behandle bekymringsmeldingen, men praksis flere steder er at lærer møter i skolens ressursteam for å ta opp en elevs mulige behov for spesialundervisning (Nilsen og Herlofsen, 2019).

I fase 2, henvisning til PPT, sendes en formell henvisning fra rektor for å få behovet for spesialundervisning sakkyndig vurdert. Det er et krav til samtykke fra foreldrene eller eleven selv før det blir gjort en sakkyndig vurdering og før det fattes enkeltvedtak om spesialundervisning, (jf. Opplæringsloven, 1998, \$ 5-4 annet ledd). I henvisningsskjemaet bør elevens styrker og utfordringer vektlegges, og i tillegg til individuelle forhold bør faktorer relatert til hva skolen har gjort gjennom tilpasning av den ordinære opplæringen vektlegges (Nilsen \& Herlofsen, 2019).

I fase 3, sakkyndig vurdering av eleven, utarbeides en sakkyndig vurdering av PPT både med bakgrunn i opplysninger som skolen har oversendt, men også egne undersøkelser (samtaler med foreldre, eleven, skolen og observasjoner og kartlegginger) (Nilsen \& Herlofsen, 2019). Den sakkyndige vurderingen skal ifølge Opplæringsloven, (1998, \$5-3) utrede og ta standpunkt til elevens utbytte av det ordinære opplæringstilbudet, og på bakgrunn av utredningsdelen komme med tilrådninger. Tilrådningen skal inneholde opplæringsmål for eleven, og elevens muligheter i en ordinær opplæring og hvilken opplæring som gir et forsvarlig opplæringstilbud (Utdanningsdirektoratet, 2019).

I fase 4, vedtaksfasen, skal skolen vurdere og avgjøre om eleven har rett til spesialundervisning basert på den sakkyndige vurderingen PPT har utarbeidet. Skoleeier, ved rektor/eventuelt en annen leder ved skolen har myndighet til å fatte enkeltvedtak om spesialundervisning. Dersom retten til spesialundervisning innvilges, skal råd i sakkyndig vurdering og enkeltvedtak operasjonaliseres i lys av LK 2006 (Utdanningsdirektoratet, 2006).

I fase 5, planlegging- og gjennomføringsfasen, skal vedtak om spesialundervisning følges opp. Opplæringsloven (1998) krever at en individuell opplæringsplan (IOP) som viser mål og innhold skal utarbeides (\$ 5-5). Skolen har hovedansvar for å utarbeide IOP, den er et arbeidsverktøy for skolen/læreren for å sikre at elevens opplæringstilbud blir i samsvar med det som eleven har rett til etter enkeltvedtaket (Utdanningsdirektoratet, 2019). 
Planen skal bygge på enkeltvedtaket og samtidig ses i sammenheng med den sakkyndige vurderingen fra PPT (Nilsen \& Herlofsen 2019). IOP gjelder for et helt skoleår, det vil si at den skal evalueres hvert år.

I fase 6, evalueringsfasen, står oppfølging av IOP sentralt, og læreren er ansvarlig for dette. Her vil evaluering av elevens læringsmål, både kortsiktige og langtidsmål være sentrale. Læreren vil sammen med eleven og/eller foreldrene vurdere om mål skal justeres eller nye mål skal utformes.

Parallelt i denne prosessen, tiltakskjeden, står også elevens rett til medvirkning sterkt (UNESCO, 2003). Artikkel 12 understreker at barn har rett til å bli hørt i alle sider ved saker som vedgår dem, og at profesjonelle har et særlig ansvar for å se til og legge til rette for at denne rettigheten blir realisert. I tillegg må lærerne kjenne til flere artikler fra Barnekonvensjonen (UNESCO, 2003). Lundy (2007) fremhever spesielt; artikkel 2, det at barn har rett til vern mot diskriminering, artikkel 3, det at voksne skal gjøre det som er best for barn, artikkel 5 , det at foreldrene har rett til å gi de rådene de mener er best for barnet, artikkel 13, det at alle barn har rett til å få informasjon om det de lurer på og rett til å gi uttrykk for det de mener, så lenge det ikke bryter med andres rettigheter samt artikkel 19 som sier at alle barn har rett til at ingen misbruker dem (UNESCO, 2003). Denne kjennskapen til artiklene er viktig fordi artikkel 12 ikke kan ses isolert (Lundy, 2007), slik den ofte gjøres i diskusjoner om barns medvirkning i beslutningstakinger i skolen.

\section{Metode}

For å besvare artikkelens forskningsspørsmål har vi fulgt prosedyrene for et litteratursøk basert på Krumsvik og Røkenes (2016). Gjennom et litteratursøk i to utvalgte databaser (IDUNN og ORIA) har målet vært å skaffe en systematisk oversikt og få en kjennskap til aktuell litteratur og resultater fra andre forskningsstudier innenfor vårt fagområde. Figur 1 viser litteratursøket som en iterativ prosess hvor en tar utgangspunkt i noen hovedsteg. Stegene bygger på hverandre, men en må ofte arbeide frem og tilbake mellom de forskjellige stegene flere ganger (Krumsvik \& Røkenes, 2016, s. 65). 


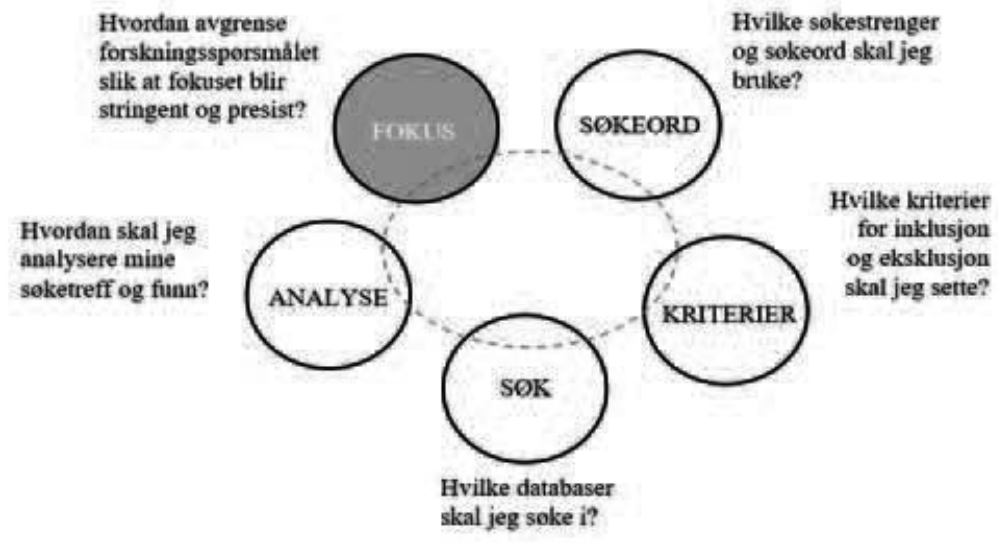

Figur 1: Oversikt over litteraturs $\emptyset$ kets prosess

(Krumsvik \& Røkenes, 2016, s. 65).

For å dokumentere søket og vise dets transparens har vi i tabell 1 laget en oversikt over hvilke kriterier søket vårt inkluderer og ekskluderer. Vi gjorde også søk i det som kalles "grey literature»; styringsdokumenter og forskningsrapporter (Krumsvik \& Røkenes, 2016) og videre supplerte vi med tilleggssøk som "hand search» for å få tak i litteratur som ikke er indeksert. Lite forskning og fokus på den spesialpedagogiske tiltakskjeden og konteksten denne står i (Herlofsen, 2014; Nordahl et al. 2018), gjorde det nødvendig å supplere med tilleggssøk. Et eget søk med engelske begrep/termer ble gjort for å fange opp engelsk litteratur. Ettersom vår problemstilling er avgrenset til lærerens rolle og ansvar i den spesialpedagogiske tiltakskjeden ble søket avgrenset fra innføringen av LK06. I Tabell 1 er søkeordene spesialpedagogisk tiltakskjede, lærerens rolle og individuell opplæringsplan inkludert. 
Lise Øen Jones og Elisabeth Hesjedal

Tabell 1. Inklusjons- og eksklusjonstabell for søk i databaser

\begin{tabular}{|c|c|c|}
\hline & Inklusjonskriterier & Eksklusjonskriterier \\
\hline Årsavgrensning & 2006-2019 & Alt før 2006 \\
\hline Søkebaser & ORIA, Idunn & $\begin{array}{l}\text { Web of Science, } \\
\text { Google Scholar, } \\
\text { Eric }\end{array}$ \\
\hline Språk & Norsk og engelsk & \\
\hline Publikasjonstype & $\begin{array}{l}\text { Fagfellevurderte artikler, dr.- } \\
\text { avhandlinger, fagbøker, St. } \\
\text { meldinger/melding til Stortinget, } \\
\text { NOU, forskningsrapporter }\end{array}$ & $\begin{array}{l}\text { BA og } \\
\text { masteroppgaver }\end{array}$ \\
\hline Søkeord & $\begin{array}{l}\text { (tiltakskjeden*) OR “individuell } \\
\text { opplæringsplan" OR IOP) ("lærerens } \\
\text { rolle” OR lærerrollen) } \\
\text { Chain of actions* Individual educa- } \\
\text { tional plan* OR IEP OR teachers role* }\end{array}$ & Individuell plan \\
\hline
\end{tabular}

\section{Søkeresultater}

Som det går frem av Tabell 2, ga søket med de gitte inklusjonskriteriene og en avgrenset tidsperiode svært få resultater. I IDUNN fikk vi 23 treff og i ORIA 17. Ved gjennomgang av titler og abstrakt i søket satt vi igjen med 5 relevante søk, ved gjennomlesing av disse artiklene og en NOU viste det seg at problemstilling og søkeord for dette litteratursøket kun hadde ett relevant treff. Dette treffet var en Phd.-avhandling av Herlofsen (2013). Avhandlingen har treff som inkluderer tiltakskjeden og elevens medvirkning. Lærerens rolle i tiltakskjeden er ikke det primære fokuset i avhandlingen, men i gjennomgangen av tiltakskjeden blir lærerens rolle i tilmelding- og IOP- fasen tatt opp. Ved å bruke de engelske søkeordene fikk vi 6 treff i IDUNN, men ingen av funnene var relevante for vårt søk. I ORIA fikk vi 70 treff, etter screening av tittel og abstract var det heller ikke her relevante treff. Vi var på forhånd klar over at temaet for søket er en kombinasjon som det er gjort lite forskning på (jf. innledning). Våre hovedfunn er i rapportert i tabell 2 (jf. Vedlegg 1). Som 


\begin{tabular}{|c|c|c|c|c|}
\hline 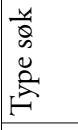 & 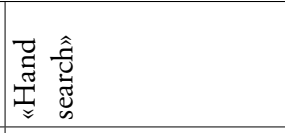 & 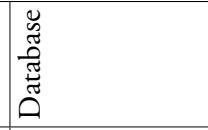 & 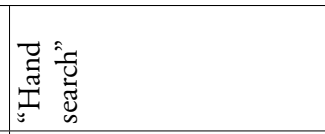 & T) \\
\hline 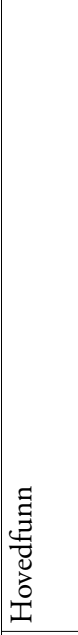 & 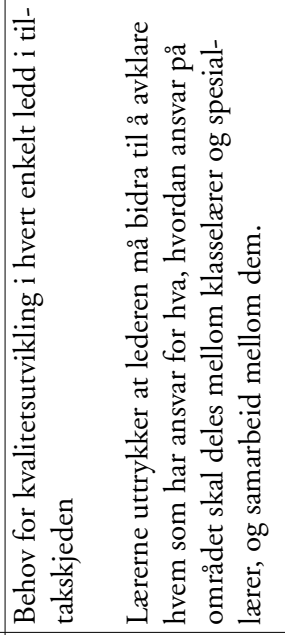 & 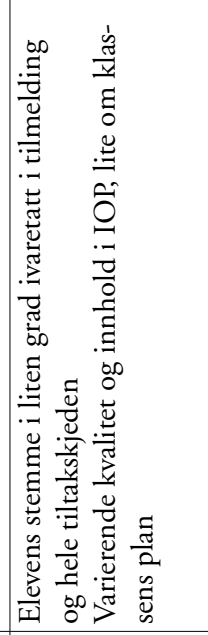 & 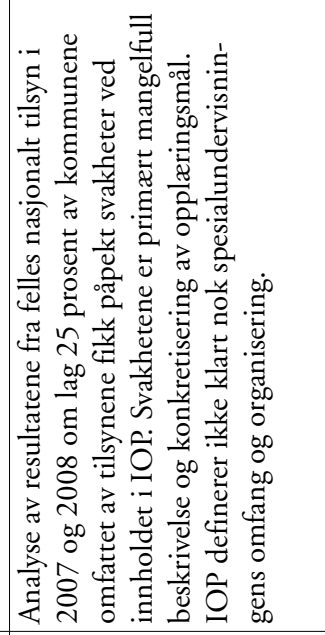 & 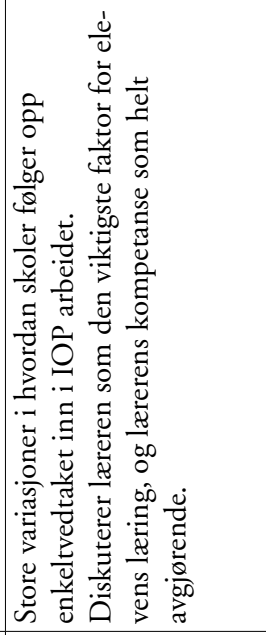 \\
\hline 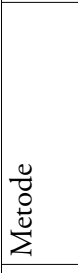 & 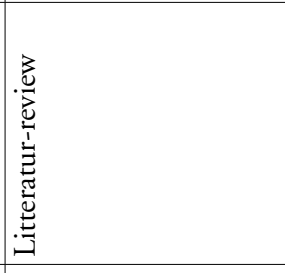 & 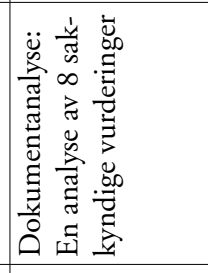 & 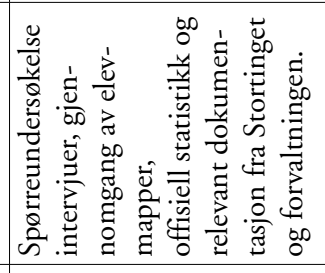 & 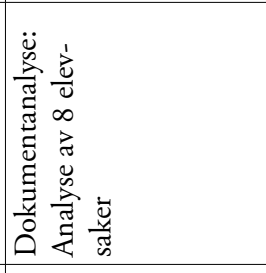 \\
\hline 莺 & 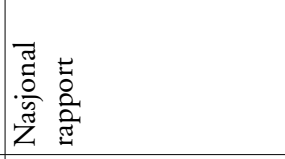 & $\frac{\theta}{\pi}$ & 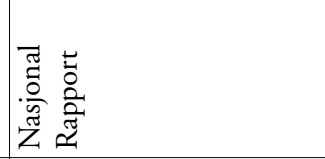 & 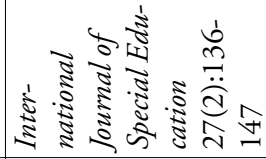 \\
\hline$\underset{ت}{\stackrel{\Xi}{E}}$ & 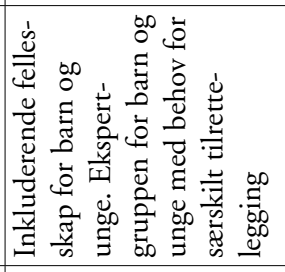 & 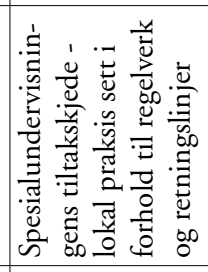 & 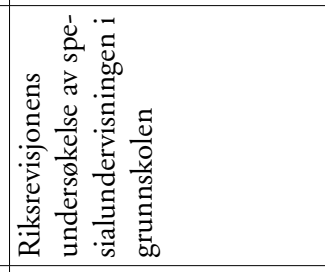 & 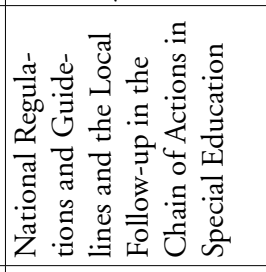 \\
\hline 这 & $\stackrel{\infty}{\stackrel{\sim}{*}}$ & 离 & 官 & $\stackrel{\sim}{\sim}$ \\
\hline 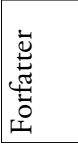 & 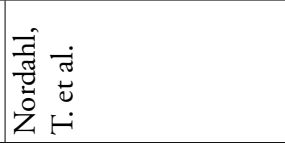 & 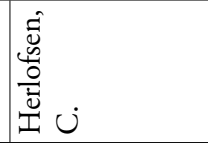 & 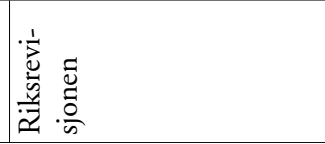 & 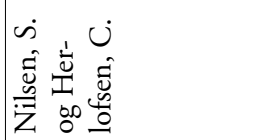 \\
\hline
\end{tabular}


det går frem av tabellen er det en fagfellevurdert artikkel og to nasjonale rapporter som faller inn under vår søkestrategi når vi utvider søket med et «hand search». Selve søket ga kun ett relevant treff (Herlofsen 2013).

\section{Diskusjon:}

Før vi diskuterer funn fra litteratursøket, vil vi som nevnt tidligere, bruke en modell inspirert av Lindensjø og Lundgren (2000) som en analytisk linse for å besvare vår problemstilling. På formuleringsarenaen vises det til relevante føringer på departementsnivå, for eksempel Kunnskapsdepartementet (Figur 2). Utdanningsdirektoratet utgjør i denne konteksten nivået i modellen hvor oppgaven er å overføre formuleringsarenaens intensjoner, gjeldende lovverk og styringsdokumenter slik at intensjoner lar seg gjennomføre i skolehverdagen. Realiseringsarenaen i modellen beskriver hvordan praksis faktisk arter seg, og hvordan den oppfattes av lærere og elever. Gjennom eksisterende forskningslitteratur blir denne oppfattelsen implisitt beskrevet (Barneombudet, 2017; Herlofsen, 2014; Nordahl et al., 2018).

Tre hovednivå (Modell inspirert etter Lindensjø \& Lundgren 2000)

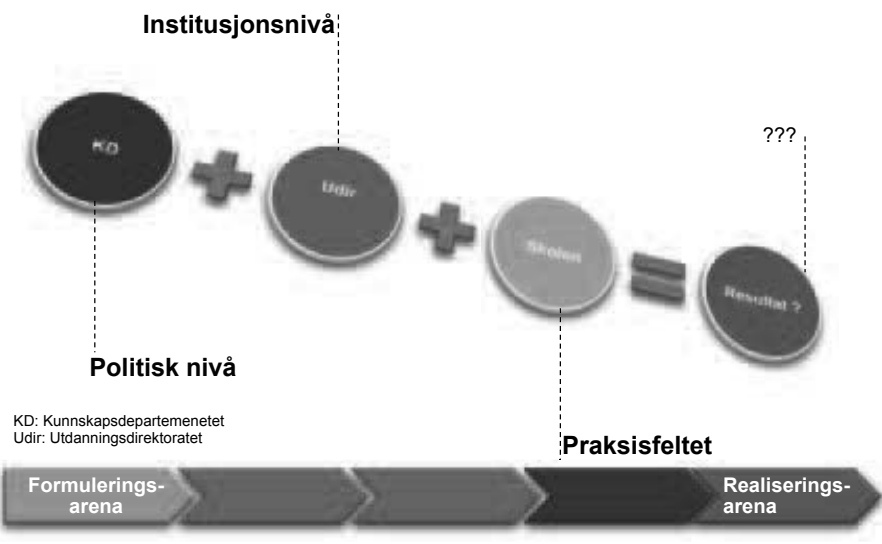

Figur 2: Formulerings- og realiseringsarenaen 


\section{Lareren rolle og ansvar}

Læreren er helt sentral i å ivareta elevens rettigheter. Det er læreren som møter eleven hver dag og som vet hvilke behov elevene i klassen kan ha. Læreren er gjerne den som er igangsetter og utfører de første kartlegginger og som skal følge opp de to siste fasene i den spesialpedagogiske tiltakskjeden, utarbeiding og gjennomføring av IOP og evaluering av IOP. Elevens beste er kjernespørsmålet i all opplæring. I overordnet del av læreplanverket (LK06) (Utdanningsdirektoratet, 2006), presiseres det at læreren som klasseleder skal legge til rette for et trygt og variert læringsmiljø med fokus på elevens faglige og sosiale utvikling og gi eleven realistiske forventninger (Utdanningsdirektoratet, 2006, s. 18). Læreren kan også få god støtte fra andre yrkesgrupper og tjenester eksempelvis PPT, dersom en elev har utfordringer, men det står ingenting om lærerens spesifikke ansvar for å følge dette opp (Utdanningsdirektoratet, 2006).

I lærerprofesjonens etiske plattform fremheves lærerens ansvar for å fremme elevens beste, og videre at læreren skal formidle sannferdig kunnskap, $\mathrm{og}$ at en faglig god tilrettelegging er avgjørende (Utdanningsforbundet, 2012). Lærerens ansvar i å følge opp en elevs behov er presisert i $\$ 5-4$ i Opplæringsloven (1998). Når det gjelder ansvaret undervisningspersonalet har, handler det om å vurdere om en elev trenger spesialundervisning og å melde fra til rektor dersom eleven har behov for det. I de nasjonale retningslinjer felles for alle lærerutdanningene står det blant annet at som lærer skal en være i stand til å legge til rette for utvikling, læring og danning hos barn og unge (UHR, 2018). Ifølge Nilsen og Herlofsen (2019) er det viktig at den lokale oppfølgingen av regelverket for spesialundervisning også inneholder støtte til skolene, slik at det ikke bare stilles krav til skolene om å følge opp regelverket (Nilsen \& Herlofsen, 2019).

\section{Elevens medvirkning}

Når det gjelder elevens medvirkning, gir Tabell 3 en oversikt over elevens medvirkning i de ulike fasene i tiltakskjeden, og aktualiserer hvilke lovhjemler som er knyttet til de ulike fasene i tiltakskjeden. Her er det viktig å merke seg at artikkel 12 står i et avhengighetsforhold til de andre artiklene som er nedfelt i Barnekonvensjonen (UNESCO, 2003). En praktisk kon- 
sekvens av artikkel 12 er at den bare kan forstås når den blir lest og tolket i lys av de andre rettighetene i konvensjonen. Lundy (2007) utarbeidet derfor en modell der artikkel 12 ble tolket i lys av andre rettigheter, dvs. artiklene 2, 3, 5, 12, 13 og 19 (UNESCO, 2003).

Tabell 3: Oversikt over tiltakskjedens faser og elevens medvirkning

\begin{tabular}{|c|c|}
\hline $\begin{array}{l}\text { Fasene i den spesial- } \\
\text { pedagogiske tiltaks- } \\
\text { kjeden }\end{array}$ & Elevens medvirkning \\
\hline Bekymringsfasen & $\begin{array}{l}\text { Eleven må bli informert og ha mulighet til å være med i } \\
\text { dialogen omkring pedagogisk differensiering, undervis- } \\
\text { ningstiltak, kartlegging. (jf. Artikkel 12, (UNESCO, } \\
\text { 2003) og } \$ 5-4 \text { (Opplæringsloven, 1998). }\end{array}$ \\
\hline $\begin{array}{l}\text { Henvisningsfasen/til- } \\
\text { melding }\end{array}$ & $\begin{array}{l}\text { Skolen v/ lærer og rektor skal informere om videre saks- } \\
\text { gang, eleven og foreldre skal ha mulighet til å være i } \\
\text { dialog (jf. Artikkel } 12 \text { (UNESCO, 2003). }\end{array}$ \\
\hline Sakkyndig vurdering & $\begin{array}{l}\text { Samarbeid med og samtykke fra elev/foreldre gjennom- } \\
\text { føres og innhentes fra elev/foreldre før sakkyndig vurde- } \\
\text { ring (jf. Artikkel 12, (UNESCO, 2003) og } ₫ 5 \text {-4 (Opp- } \\
\text { læringsloven, 1998). }\end{array}$ \\
\hline Vedtaksfasen & $\begin{array}{l}\text { Tilbud om spesialundervisning skal så langt råd er, } \\
\text { utformes i samarbeid med eleven og foreldrene til eleven, } \\
\text { og det skal legges stor vekt på deres syn (jf. Artikkel 12, } \\
\text { (UNESCO, 2003) og } \$ 5-4 \text { (Opplæringsloven, 1998). }\end{array}$ \\
\hline $\begin{array}{l}\text { Planlegging- og gjen- } \\
\text { nomføringsfasen }\end{array}$ & $\begin{array}{l}\text { Eleven kan bli med i dialogen omkring utarbeidelse av } \\
\text { mål i IOP (jf. Artikkel 12, (UNESCO, 2003) og } \$ 5-4 \\
\text { (Opplæringsloven, 1998). }\end{array}$ \\
\hline Vurderingsfasen & $\begin{array}{l}\text { Eleven kan bli med i dialogen omkring evaluering av mål } \\
\text { og justering av IOP, samt inkluderes i det videre plan- } \\
\text { arbeidet med ev. en ny og oppdatert IOP (jf. Artikkel 12, } \\
\text { (UNESCO, 2003) og } \$ 5 \text {-4 (Opplæringsloven, 1998) }\end{array}$ \\
\hline
\end{tabular}


Modellen skal bidra til at beslutningstakere, for eksempel lærere, aktualiserer medvirkning sentrert rundt fire punkter; Space, (rom); at barn må bli gitt mulighet og sted til å uttrykke sitt syn; Voice (stemme) at barn må bli støttet i å uttrykke sine syn; Audience (lytte), at barn må bli lyttet til; og Influence (påvirkning), at barns syn må bli aktualisert. Videre er det viktig å legge til at selv om barn har rett til å medvirke (UNESCO, 2003, artikkel 12) har de også rett til ikke å delta, f.eks. å ikke mene noe om noe, ifølge Lundy (2007). Dersom et barn ikke vil involveres i saker som angår dem, fordrer det likevel at læreren er ansvarlig for/oppmerksom på å ivareta og å fremme både alles og enkeltelevers rettigheter. Rettighetene om medvirkning er spesielt viktig å være klar over, både i lys av fasene i alle ledd som inngår i tiltakskjeden og i spesialundervisningen, spesielt fordi dette er en elevgruppe som ofte er sårbar og som ikke ofte blir hørt (Barneombudet, 2017, Johnsen, 2019). Diskusjonsdelen har så langt diskutert en gjennomgang av formuleringsarenaen; hva ulike sentrale styringsdokumenter beskriver som lærerens ansvar i den spesialpedagogiske tiltakskjeden og videre elevens rett til medvirkning.

\section{Larerens ansvar for å folge opp elever som har rett på spesialundervisning}

Videre vil det diskuteres hvordan lærerens ansvar og elevens medvirkning viser seg på realiseringsarenaen. Innenfor denne avgrensingen finnes det foreløpig avgrenset empiri på feltet (Herlofsen, 2014). Hovedformålet med tiltakskjeden er både av praktisk og pedagogisk art, hvor målet er et best mulig støttesystem som kommer elevene til gode. Nilsen og Herlofsen (2019) understreker at kvaliteten i det enkelte ledd og sammenhengen mellom dem, er helt sentralt for at tiltakskjeden skal fungere best mulig. I Opplæringslovens (1998), \$5-4 om læreres ansvar for å følge opp elever med rett til spesialundervisning, er dette ansvaret lovhjemlet, mens ansvaret i tiltakskjeden er lite synliggjort. Elevens rett til medvirkning er lovhjemlet (Opplæringsloven, 1998; UNESCO, 2003), men blir i liten grad løftet frem i tiltakskjeden. Dette kommer også frem i rapportene til Barneombudet (2017) og Nordahl et al. (2018).

I Meld. St. 21, (2016-2017) var fokus rettet mot at barnehager og skoler må ha kompetanse og kapasitet til å avdekke tidlig dem som har behov for spesialpedagogisk hjelp eller spesialundervisning. I tillegg til spesialpedago- 
gisk kompetanse er juridisk kompetanse sentralt. Papendorf (2012) påpeker at reglene for spesialundervisning har stort rom for profesjonelt skjønn. Fjørtoft, Åm og Farstad (2017) viser til at foreldre etterlyser mer juridisk kompetanse i skolen både hos undervisningspersonell og hos rådgivere som skal sørge for at elevers rettigheter etterleves. De viser videre til at skjønnsvurderinger har stort tolkningsrom og kan utnyttes av skoleeiere for å «slippe å bruke mye penger» på spesialundervisning.

Barneombudet (2017) melder også at skoler ikke i stor nok grad overholder sin informasjonsplikt i forbindelse med vedtak om spesialundervisning. Dette kan føre til at foreldre og barn ikke er godt nok informert om innholdet i vedtaket og hva vedtaket innebærer. Hva kan dette skyldes? I Norges offentlige utredninger nr. 18 (2009, s. 196) vises det til at lovhjemmelen knyttet til spesialundervisning gir elevene rett til å delta i utforming av vedtak om tilrettelegging (Opplæringsloven, 1998, $\$ 5-4$, 3. ledd), men at innholdet i hvordan medvirkningen kan skje/tilrettelegges for, ikke er konkretisert.

\section{Hvordan kan elevers rett til medvirkning ivaretas?}

Gjennom styringsdokumenter på formuleringsarenaen kommer det tydelig frem at barn har rett til å medvirke. Utfordringen er derimot at artikkel 12, ledd 1 og 2 (UNESCO, 2003) ikke er konkret utformet og derfor åpen for en skjønnsmessig vurdering av hvordan medvirkning kan tilrettelegges og aktualiseres. En annen utfordring er at det ikke er tatt høyde for at artikkel 12 må ses i lys av de andre aktuelle artiklene i Barnekonvensjonen (UNESCO). Videre ser vi at ansvar for realisering av barns medvirkning i denne sammenhengen blir lagt på læreren (Opplæringsloven 1998, § 5-4; Lundy, 2007). Herlofsen (2013) viser også i sin avhandling at elevens stemme i liten grad er ivaretatt i tilmeldingsfasen og hele tiltakskjeden. Det er viktig at lærer har kunnskap om relasjoner og rettigheter slik at hen i best mulig grad kan kommunisere med barnet for slik å få ta del i hvilke tanker og opplevelser barnet har om saken. Herlofsen og Nilsen (2016) påpeker at $\mathrm{i}$ alle faser gjelder det at aktørene må forsøke å sette seg inn i, tolke og forstå regelverk og retningslinjer, slik at en er klar over både styring og forpliktelser en har. 
Barn har også har rett til å frasi seg retten til medvirkning (Barnekonvensjonen, 2003, artikkel 12). Med denne dikotomien, beskyttelse vs. deltagelse, kan læreren derfor stå overfor ulike utfordringer. I slike tilfeller bør man sette artikkel 12 i spill og vurdere artiklene 2, 3, 5, 12, 13 og 19 sammen med artikkel 12, (Barnekonvensjonen, 2003; Lundy, 2007) for å forsikre seg om at barns rett til medvirkning ivaretas. Ifølge Vis og kollegaers (2011) studie knyttet til barnevernsfeltet, om barns medvirkning, vises det til at barna mener at dersom de får medvirke oppleves det; mer rettferdig, at du lærer av det, at det fører til bedre avgjørelser, og at du får informasjon, og at du forstår mer av det som skjer (Vis, Strandbu, Holtan \& Thomas, 2011). Tar vi med oss disse synspunktene over til tiltakskjeden, kan det tenkes at dersom barn får medvirke igjennom alle faser, vil dette kanskje bidra til å skape mer forståelse for situasjonen, spesialundervisningen for det enkelte barn. Det kan også være en medvirkende faktor til å endre den profesjonelle praksis til i større grad å ta utgangspunkt i barnets behov. Skal man få til en slik endring, må det nettopp være lærere som legger til rette for medvirkning på beslutningsnivå (UNESCO 2003; Lundy, 2007), eksempelvis slik som de ulike fasene i tiltakskjeden. For å sikre dette bør man derfor «overvåke» de ulike fasene i tiltakskjeden med hensyn til barns rett til å medvirke (Lundy, 2003; UNESCO, 2003). Dette kan gjøres for eksempel ved å ha en form for dokumentasjon som viser når, hvor og hvordan barnet har medvirket, hvordan beslutning i de ulike fasene har blitt rapportert tilbake til barnet, og hvilke konsekvenser de ulike beslutningene har eller kan gi (Hesjedal, under utgivelse).

Når det gjelder hvordan barn har medvirket eller tiltak for hvordan barn kan medvirke, må medvirkning tenkes ut fra mer enn bare en tilrettelegging for samtale basert på trygg relasjon. Man bør tenke tilrettelegging utfra hvilke aktuelle kommunikasjonsalternativer barn med særlige behov har (Lundy, 2007). Dette fordrer at lærer må være i posisjon til å arbeide i forbindelse med tiltakskjeden slik at medvirkning blir aktivisert og realisert (Lundy, 2007; UNESCO, 2003). Et sterkere fokus på medvirkning i tiltakskjeden gjør at barnet (og foreldrene) får bedre informasjon om saken (fasene i tiltakskjeden) som berører dem. På denne måten vil barnet kjenne seg ivaretatt i større grad enn det som Barneombudet (2017) viser til. 


\section{Sammendrag og konklusjon}

Resultatet av vårt litteratursøk og gjennomgang av dokumenter viser at vi i større grad trenger å se tiltakskjeden ut fra et medvirkningsperspektiv. I lys av våre erfaringer fra praksisfeltet og manglende forskning på feltet er det sentralt å vurdere hvorvidt man har lagt til rette for å gi barna muligheter for medvirkning på realiseringsarenaen. En slik endring vil for eksempel kreve kunnskap om juss i lærerutdanningen, og også hvordan slike tiltak kan se ut og videreutvikles i lys av rettigheter og konvensjoner (Fløysvik Nordum 2019; Opplæringsloven 1998, og Artikkel 12 (UNESCO, 2003). Herlofsen (2014) påpeker at hva som skjer i de ulike fasene i den spesialpedagogiske tiltakskjeden i stor grad avhenger av kompetansen til fagfolk. Det utøves ofte skjønn, derfor kreves god innsikt i pedagogikk og spesialpedagogikk, og at en har kunnskap om barns læring og utvikling og hvordan ulike tiltak kan stimulere til en god utvikling.

Vår gjennomgang av litteratur på formuleringsarenaen viser at lærerens rolle og ansvar i stor grad er rettet mot saksgang, prosedyrer og manglende kompetanse, særlig i utarbeiding av IOP. Lærerens rolle og ansvar for elevens rett til og medvirkning i forbindelse med spesialundervisning, er i liten grad diskutert i forskningslitteraturen. Ifølge Nordahl et al. (2018) uttrykker lærere at lederen må bidra til å avklare hvem som har ansvar for hva, hvordan ansvar på området skal deles mellom klasselærer og spesiallærer, og samarbeidet mellom dem. Nilsen og Herlofsen (2019) poengterer at forbedringer i tiltakskjeden ikke bare skal bidra til å ivareta det formelle administrative formålet, hvor fokus blir på at regler skal følges. Et slikt perspektiv vil være på linje med det Hausstätter (2012) beskriver som et smalt perspektiv på spesialundervisning. En forbedring av tiltakskjeden handler om å fà til et godt fungerende støttesystem i praksis (Nilsen og Herlofsen 2019).

Læreren har et særlig ansvar for å følge opp elever for best å imøtekomme rettighetene i $\$, 5-1,5-4$, og 5-5 (Opplæringsloven, 1998) og barns rett til medvirkning (UNESCO, 2003, artikkel 12). Derfor er det behov for mer kunnskap og forskning knyttet til teori og praksis som berører den spesialpedagogiske tiltakskjeden (Herlofsen, 2014; Lundy, 2007). Vi ser også behov for et sterkere innslag av juridiske emner i lærerutdanningene da lærerne også arbeider med elever som har behov for ulik hjelp og støtte gjennom sitt utdanningsløp. 
Målet med denne artikkelen har vært å løfte frem lærerens rolle i grunnskolen og ansvaret en har for å identifisere og følge opp elever som har rett på spesialundervisning etter $\$ 5-1$ i Opplæringsloven (1998) i forbindelse med den spesialpedagogiske tiltakskjeden. Videre var elevens stemme inkludert gjennom å sette søkelys på hvordan elevens rett til medvirkning kan ivaretas i tiltakskjeden. Gjennom et litteratursøk avgrenset til å gjelde sentrale dokumenter knyttet til tiltakskjeden og lærerens rolle fra perioden 2006 til 2019 viste søket i nasjonale databaser (ORIA og IDUNN) svært få treff. Sentrale styringsdokumenter og lovverk beskriver saksgangen i tiltakskjeden, men tydelige beskrivelser av læreren som aktør i tiltakskjeden er i liten grad beskrevet. Det samme gjelder for hvordan tilrettelegge for elevens medvirkning i tiltakskjeden. Dette er et paradoks særlig når vi ser fra erfaring og forskning at læreren er en så viktig aktør i første, femte og sjette fase i tiltakskjeden. I \$ 5-4 (Opplæringsloven, 1998) går det tydelig frem hva som er undervisningspersonalets ansvar med tanke på å vurdere elevens behov for spesialundervisning og til å melde fra rektor ved behov.

Resultatet fra denne studien viser mangler i forhold til IOP-arbeidet, både når det gjelder å følge opp enkeltvedtaket samt selve utformingen av IOP. Litteraturen på feltet har vært/er rettet mer mot saksgang og prosedyrer enn mot realisering når det gjelder lærers ansvar og barns medvirkning. Retten til spesialundervisning må ikke bare bli en «rett på papiret». For å kunne gi et forsvarlig opplæringstilbud mener vi som Herlofsen (2013) og Nilsen og Herlofsen (2019), at dette er avhengig av at det arbeidet som gjøres i de ulike leddene i tiltakskjeden blir gjennomført etter gjeldende lovverk og retningslinjer. Vår gjennomgang viser også at juridisk kompetanse hos lærere er viktig. Utdanningsfeltet må ta dette inn over seg, sammen med et større fokus på barns rett til medvirkning i utdanningsløpet.

\section{Referanser}

Barneombudet. (2017). Uten mål og mening? Elever med spesialundervisning i skolen. Hentet fra http://barneombudet.no/wp-content/uploads/2017/03/Bo_rapport_enkeltsider.pdf 
Befring, E. (2018). De pedagogiske kvalitetene. Løfterike muligheter for barn og unge. Oslo: Universitetetsforlaget.

Biesta, G. J. (2013). Beautiful Risk of Education, Routledge. ProQuest Ebook Central, https://ebookcentral.proquest.com/lib/bergen-ebooks/detail. action?docID $=4185950$.

Hesjedal, E. (under utgivelse). Educational psychology counsellors views` about children's participation in educational decision making: A thematic analysis. The International Journal of Children's rights.

Fjørtoft, H., Åm, V. G. \& Farstad, E.P. (2017). Juridisk literacy i skolen. Ikke-juristers lovtekstlesing og rettsanvendelse. Nordic Journal of Literacy Research (3)1-14. http://dx.doi.org/10.23865/njlr.v3.685

Fløysvik Nordum, J.C. (2019). Rettigheter til barn og unge med funksjonsnedsettelser. I E. Befring, K-A. B. Næss \& R. Tangen (Red.). Spesialpedagogikk. (s. 91-105). Oslo: Cappelen Damm AS.

Haug, P. (2013). Tilpasset opplæring for den enkelte i felleskapet. I Krumsvik, R. J., \& Säljö, R. (2013). Praktisk-pedagogisk utdanning: en antologi. (s. 415-440). Bergen: Fagbokforlaget.

Hausstätter, R.S. (2012). Inkluderende spesialundervisning. Bergen: Fagbokforlaget.

Herlofsen, C. (2014). Spesialundervisningens tiltakskjede: lokal praksis sett $i$ forhold til regelverk og retningslinjer: en kvalitativ dokumentanalyse av elevsaker. Doktorgradsavhandling. Oslo: Unipub forlag.

Herlofsen, C., \& Nilsen, S. (2016). Spesialundervisning i spenningsfeltet mellom juridisk regelverk og lokal praksis. I K., Andenæs, \& J., Møller. (Red.), Retten i skole: mellom pedagogikk, juss og politikk (s. 138-158). Oslo: Universitetsforlaget.

Johnsen, B. (2019). Spesialpedagogiske røtter og fagets utvikling. I E. Befring, K.-A. B. Næss \& R. Tangen (Red.). Spesialpedagogikk. (6.utg, s. 107128). Oslo: Cappelen Damm AS.

Krumsvik, R.J. \& Røkenes, F. (2016). Litteraturreview i phd. avhandlingen I R. J. Krumsvik (Red.) En doktorgradsutdanning i endring (s. 51-92). Bergen: Fagbokforlaget

Kunnskapsdepartementet. St. melding 21 (2016-2017). Larelyst-Tidlig innsats og kvalitet skolen. 
Lundy, L. (2007). 'Voice' Is Not Enough: Conceptualizing Article 12 of the United Nations Convention on the Rights of the Child. British Educational Research Journal 33(6) 927-942.

Nilsen, S. \& Herlofsen, C. (2109). Spesialundervisningens tiltakskjede. I E. Befring, K -A B. Næss \& R. Tangen (Red.). Spesialpedagogikk. (6.utg.s. 218-248). Oslo: Cappelen Damm AS.

Papendorf, K. (2012). Rett for alle? Rettsliggjøring og rettsferne personers mulighet til à mobilisere retten. Oslo: Novus forlag.

Riksrevisjonen (2010 2011). Riksrevisjonens undersøkelse av spesialundervisningen i grunnskolen. Dokument 3:7. Fagbokforlaget: Bergen

Svele, A.M., Driscoll, H., Helmen, I., Holm, R., Jensen, I., Kopp. A., ... Sjøli Eikenes, Å. (2018). Juss for skoleledere. Oslo: Universitetsforlaget.

UHR (2018). Nasjonale retningslinjer for lærerutdanningene. Hentet fra https://www.uhr.no/temasider/nasjonale-retningslinjer-for-larerutdanningene/

Utdanningsdirektoratet. (2019). Veilederen Spesialundervisning. Hentet fra https://www.Utdanningsdirektoratet, 2019.no/laring-og-trivsel/sarskiltebehov/spesialundervisning/Spesialundervisning/

Utdanningsdirektoratet. (2006). Læreplanverket for Kunnskapsløftet. Hentet fra https://www.udir.no/laring-og-trivsel/lareplanverket/

Utdanningsforbundet. (2012). Lærerens etiske plattform. Hentet fra https://www.utdanningsforbundet.no/larerhverdagen/profesjonsetikk/o m-profesjonsetikk/larerprofesjonens-etiske-plattform/

UNICEF. (2003). FNs konvensjon om barnets rettigheter (U. N. C. C. o. 1989, Trans.). [Oslo]: Barne- og familiedepartementet.

Vis, S.A., Strandbu, A., Holtan, A., \& Thomas, N. (2011). Participation and health - a research review of child participation in planning and decision-making. Child \& Family Social Work, 16(3) 325-335. doi: 10.1111/j.1365-2206.2010.00743.x

Welstad, T. (2016), Tilpasset opplæring som rettslig begrep og prinsipp. I Andenæs, K., \& Møller, J. (Red.), Retten i skole: mellom pedagogikk, juss og politikk. (s. 75-96). Oslo: Universitetsforlaget. 